\title{
Analysis of Methods Innovation of Contemporary College Students' Ideological and Political Education
}

\author{
Kena Wang*, Guohong Wang
}

Qiqihar Medical University, Academy of Marxism, Qiqihar City, Heilongjiang Province, 161006

Keywords: ideological and political education; college students; innovation way

\begin{abstract}
In the social development of our country, college students are an important force for the promotion of socialist modernization in the future and shoulder the heavy responsibility of carrying forward our country's social development. Therefore, it is very important to strengthen the ideological and political education of college students. Nowadays, under the situation of a multicultural and new media era, the scientific innovation of contemporary college students' ideological and political education methods and the enhancement of the effectiveness of education have become an urgent problem for ideological and political education in colleges and universities. Through innovative educational methods, contemporary college students have a good ideological and political education with the spirit of the times, and they have achieved multi-faceted ideological and political education goals in society, schools, and families. This paper explores innovative approaches to contemporary college students' ideological and political education methods and provides valuable reference for practical teaching.
\end{abstract}

\section{Introduction}

At present, the reform of college education in our country is continuously deepening, and it has achieved good results in scientific and technological culture and personnel training. However, the contemporary college students present problems in terms of their ideological qualities and psychological status, and have become an important part of people's general concern. Moreover, contemporary college students have a relatively weak ideological consciousness, which leads to a generally low quality and level of ideological and political education for college students. Therefore, colleges and universities should, through all-round analysis, put forward scientific and pertinent ideological and political education programs in light of the actual situation, follow the party's spiritual guidelines, and steadily implement various ideological and political education work for college students. The scientific development concept is regarded as the basic principle for contemporary college students to carry out ideological and political education. At the same time, the ideological and political education content is included in the overall planning of social development.

\section{Analysis of Contemporary College Students' Ideological and Political Education}

Strengthening the ideological and political education of college students can, on the one hand, benefit the students' own good development. On the other hand, it also highlights the quality and level of China's higher education. It can also have a direct impact on the future social development. At present, the work of ideological and political education for college students has been given more attention, but there are still some drawbacks that need to be addressed. First of all, from the perspective of college students themselves, generally speaking, they can accept the party's policy objectives and maintain the party's leadership status, but they cannot grasp the party's connotations of governance, and they do not pay attention to learning political theory. Therefore, it is not easy to adapt well to the political influence in the social environment. At the same time, college students have a high degree of patriotism, but they are also vulnerable to bad social atmosphere. Moreover, contemporary college students have strong self-awareness, generally focus on self-interest, and do not have high anti-compressive ability during the period of study pressure or life pressure. From the 
perspective of colleges and universities, current colleges and universities generally attach importance to ideological and political education, and earnestly set up courses. At the same time, professional ideological and political teachers are deployed to teach, but the application of the traditional professorial model is still common, making classroom teaching not practical teaching features. The counselor's level of business is uneven, and the number of staff is unscientific. Some counselors have more work responsibilities, so they are often unable to fully carry out their ideological and political education. In addition, there are also unsatisfactory situations in setting up auxiliary classrooms in universities, and some advanced auxiliary education methods including lectures and ideological activities are lacking.

\section{The Innovation Basis of Contemporary College Students' Ideological and Political Education Methods}

Currently in the new social background development situation, colleges and universities carry out the ideological and political education of college students need to take the spirit of the party's 17th National Congress as an important guide. At the same time, in the ideological and political education of college students, it will reasonably infiltrate the scientific development concept and will train students. Form the correct concept of ideological and political education as the ultimate goal. During the work of ideological and political education for college students, it is necessary to closely link up with China's national conditions, actively keep up with the pace of development of the times and steadily move forward. Through the scientific education methods for college students, the ideological and political education work will be more charismatic and creative. In order to effectively improve the quality and effectiveness of the ideological and political education of college students, it is necessary to adopt a standardized, scientific and reasonable method of ideological and political education for college students that is advancing with the times. This is also critical to the cultivation of the ideological and political education of college students. During the education work, it is necessary to carry out extensive and profound dissemination and teaching of related educational contents, and positively influence its ideological and political work. During the process of ideological and political education in colleges and universities, education should be implemented and reformed in the actual teaching process. The prerequisite basis is to realize during the teaching practice. Therefore, there are many innovations in the ideological and political education of contemporary college students, which must be fully considered and implemented in many aspects. For example, the ideological and political education for undergraduates based on the theoretical system of socialism with Chinese characteristics is linked to concrete forms to cultivate ideological and political education for the undergraduates with the spirit of the times; to achieve the ideological and political education goals of multiple orientations (society, schools, families, etc.).

\section{The Significance of Innovation in Contemporary College Students' Ideological and Political Education Methods}

In college education, the ideological and political education content of college students is an indispensable and important aspect. It is of great significance to intensify the innovation of contemporary college students' ideological and political education methods. First, the continuous deepening of the integration of the global economy has led to the continuous improvement of the relevant standards for teaching and learning in Chinese universities, including ideological and political education. In the context of economic integration and scientific innovation, the interests of college students have become diversified. Therefore, they have exerted significant influence and tests on the concept of human life, morality, and values. In view of this situation, it is necessary for colleges and universities to continuously follow up on ideological and political education. Second, current college students are generally not deeply impressed with the construction of ideological and political education. Although universities and colleges implement ideological and political education one after another, they are usually Incompleteness and education model, so the students' understanding of ideological and political education is not profound, and it is of vital importance to 
intensify education. Third, in the current era of continuous development of Internet technology, colleges and universities are provided with more diversified ideological and political education. Under the premise of in-depth development of social networking, the ideological and political education of college students needs to strengthen innovation, perfect match with the network environment, and continuously improve the quality of education; Fourth, the long-term development mechanism for colleges and universities to implement the new requirements of ideological and political education standards. Colleges and universities belong to social organizations, and the implementation of ideological and political education has long-term characteristics. Therefore, it is necessary to strengthen the constant innovation of educational methods and make it scientific and sustainable. Fifth, it can enhance the effectiveness of ideological and political education for college students. At present, the ideological and political education in universities in China has accumulated and summarized important advanced experience during the development of decades. It provides valuable basis and guidance for colleges and universities to train qualified talents, but the traditional teaching models and methods can not be well adapted to the current situation. Social development needs. Talent training needs to be fully developed. It requires not only strong theoretical knowledge, but also good practical ability. Therefore, the ideological and political education in colleges and universities is fully connected with the internal environment and the external environment. After innovating ideological and political education methods, it is an effective guarantee for effectively improving the effectiveness of ideological and political education in Chinese universities.

\section{Important Strategies of Ideological and Political Education Methods for Contemporary College Students}

\subsection{The Mechanism of Reforming Ideological and Political Education.}

In order to effectively improve the quality of ideological and political education, relevant educators should establish special functional organizations or form ideological and political education groups to actively and fully play the role of college student organizations. And based on the ideological and political education system that has been fulfilled by the university itself, it is necessary to make scientific adjustments to the actual teaching needs and to improve and improve the ideological and political education regulations. First of all, for the improvement of the course selection system, for the setting of teaching content, teaching time, and course selection, the students' opinions should be solicited, and the scientific combination and optimization of the ideological and political education course selection activities for college students should be conducted. According to the corresponding teaching content, the Arrange for teachers and class forms. Secondly, the evaluation and evaluation mechanism for ideological and political teachers was improved and reformed, and the performance appraisal system was incorporated to appropriately increase the salaries of teachers, which led to the linking of job title assessment and welfare bonuses with student learning effectiveness and enthusiasm for participation, which could significantly improve teachers' performance. Teaching level, and stimulate their enthusiasm for teaching.

\subsection{Implementing Ideological and Political Education.}

The main education methods for ideological and political education in colleges and universities are positive and explicit education, which can promote the realization of teaching goals as soon as possible, and at the same time greatly save the cost of education. However, it also has unavoidable drawbacks. It is dull and overly direct. Especially for the current multicultural and new media era background, colleges and universities in the traditional positive form of explicit education can no longer meet the needs of the times and we must find new ways to seek ways to update. Unlike explicit education, implicit education, by definition, is a hidden, indirect education. It can be used as a means of imparting appropriate educational penetration to educational objects in a way that "moments are muted". This has been widely recognized. Therefore, current colleges and 
universities should actively explore various effective ways to realize the enrichment of ideological and political education forms for college students and carry out scientific ideological and political education. For example, to strengthen the construction of the campus network, adopt various forms of new media equipment, and use explicit education to provide implicit education. In addition, a high-quality team of teachers among the groups promotes the improvement of college students' self-education ability. Therefore, colleges and universities should actively display their subjective initiative and provide important conditions for the implementation of implicit ideological and political education.

\subsection{Enriching College Students' Ideological and Political Education.}

In the era of new media and the development of multiculturalism, the reality of the ideological and political education of college students is constantly changing, and traditional forms of subject education in colleges and universities have required a timely transformation. Under such circumstances, the external subject of the ideological and political education of college students should be developed in a diversified direction, and family, society, and the usual abandonment of negative ideas and inactions in the ideological and political education launched by college students should be positive. Parents also need to have a thorough understanding of students' ideas, daily life, and dynamic development. Through various ways of setting examples, they actively guide students to form correct ideas, adopt correct behavior standards, and strengthen family education functions. In terms of society, it provides the students with a good external environment. For example, in the student life community, they have their own advantages, and they have a number of speech event competitions, game competitions, home visits and other forms to help students develop good ideological and moral qualities. Moreover, universities, societies, and families should establish a good cooperative relationship and form a positive long-term linkage mechanism for ideological education among college students. After constructing a cooperative education approach, the actual effectiveness of ideological and political education for college students can be effectively promoted.

\subsection{Continuous Improvement of Ideological and Political Education Content.}

First, we should take existing ideological and political education resources, effectively integrate ideological and political education before, during, and after classes so that students can correctly master the learning methods, and be able to integrate ideological and political theory knowledge and practically learn to use it. Second, multimedia technology is used to display relatively abstract and theoretical knowledge that is not easy to understand. Case teaching methods, courseware display methods, etc. can be used to teach, and abstract forms can be expressed in an intuitive and concrete manner to improve students' ability to understand concepts. Next, classroom theory learning is organically combined with extracurricular information collection, full use of modern mobile devices for education. For example, to build a related We-Chat public platform, the theme is ideological and political education. It pushes information on ideological and political education activities inside and outside the campus and the latest political hotspot information content, etc., and provides students with a broad platform for exchanges, thereby realizing the continuous expansion of colleges and universities. The scope of ideological and political education, and improve the quality of education.

\section{Conclusion}

College students shoulder the hope of the future development of the motherland, and it is crucial for them to carry out ideological and political education. Nowadays, under the background of the rapid development of social economy and science and technology, in order to better adapt to the new situation, colleges and universities should pay attention to constantly innovating the methods of ideological and political education for college students, keep pace with the times, and make adjustments and improvements accordingly. With advanced ideological and political education methods, we can satisfy the effect of education and promote the establishment of a higher ideological and political quality for college students. 


\section{Acknowledgements}

Fund Project: Study on the ideological and political theory courses of Heilongjiang Province's higher education teaching reform project and the "four-entering and four-letter" special education reform study Special project on the evaluation of the ideological and political theory courses exam evaluation system and evaluation system, project number SJGSY2017013

\section{References}

[1] Liu Jing. Challenges and Methods of Ideological and Political Education for "Post-95" Undergraduates in the Internet + Era[J]. Education in Times, 2017(07):133-134.

[2] Wang Zhongyan. A Preliminary Exploration of the Reform and Innovation of Contemporary University Students' Ideological and Political Education [J]. Curriculum Education Research, 2017(36):43-44.

[3] Guan Liping, Zhang Chengke. Status quo and innovation of college students' ideological and political education methods [J]. Education in Times, 2015(22):100-101.

[4] Meng Xu. Contemporary University Student Ideological and Political Education Method Innovation [J]. Era Education, 2016(16):20-21.

[5] Zhang Yanhong. Some thoughts on the innovation of college students' ideological and political education methods [J]. Era Education, 2016(21):119.

[6] Wang Lu. Innovative ways of ideological and political education for college students [J]. Modern Vocational Education, 2018(01): 222.

[7] CHEN Liang, ZHAO Fen. Research on the innovation of college students' ideological and political education methods [J]. Examination Weekly, 2018(10):115. 